Nuclear Waste Policy Act (Section 112)

\title{
Environmental Assessment Overview
}

Yucca Mountain Site, Nevada Research and Development Area, Nevada

May 1986 


\section{Nuclear Waste Policy Act}

(Section 112)

\section{Environmental Assessment Overview}

Yucca Mountain Site, Nevada Research

12

$\infty$

$\nabla$

May 1986

$M$

-

a. and Development Area, Nevada 
The Nuclear Waste Policy Act of 1982 (the Act) established a process for the selection of sites for the disposal of spent nuclear fuel and high-level radioactive waste in geologic repositories. The first steps in this process were the identification of potentially acceptable sites and the development of general guidelines for siting repositories. In February 1983, the DOE identified nine sites in six States as potentially acceptable for the first repository. The Yucca Mountain site in Nye County, Nevada, was identified as one of those sites. The general guidelines were issued in November 1984 as Title 10 of the Code of Federal Regulations, Part 960. The DOE is now proceeding with the next step in the site-selection process for the first repository: the nomination of at least five of the nine potentially acceptable sites as suitable for site characterization, which is a program of detailed studies.

The Act requires that site nomination be accompanied by an environmental assessment (EA). The DOE has prepared EAs for the nominated sites through a process that provided opportunity for public input. Public hearings were held during March, April, and May 1983 to obtain recommendations on the issues to be addressed in an EA. All such recommendations were considered in preparing the EAs. The DOE issued draft EAs for public review and comment in December 1984 and conducted a series of public hearings in February and March 1985. The issues raised in the comment letters and hearings were considered in preparing the final EAs. "These issues are addressed in a comment-response document appended to the final EAs (Appendix C).

The information presented in the EAs is derived from hundreds of technical reports containing more-detailed data and analyses. All of these reference documents are avallable to the public in various 1 ibraries and reading rooms; a listing of their locations is given in Appendix B.

After the nomination, the Secretary is required by the Act to recommend to the President not fewer than three of the nominated sites for characterization as candidate sites for the first repository. This recommendation will be submitted and documented in a separate report that is being issued separately from this environmental assessment. Af ter submittal, the Act provides the President 60 days to approve or disapprove the candidate sites. The President may delay his decision for up to six months if he determines that the information supplied with the recommendation of the Secretary is insufficient to permit a decision within the 60-day period. If the President does not approve, disapprove, or delay the decision, the candidate sites shall be considered approved. After the President approves the candidate sites, the DOE will start site characterization. 
In February 1983, the U.S. Department of Energy (DOE) identified the Yucca Mountain site in Nevada as one of nine potentially acceptable sites for a mined geologic repository for spent nuclear fuel and high-level radioactive waste. The site is in the Great Basin, which is one of five distinct geohydrologic settings considered for the first repository. To determine their suitability, the Yucca Mountain site and the eight other potentially acceptable sites have been evaluated in accordance with the DOE's General Guidelines for the Recommendation of Sites for the Nuclear Waste Repositories. These evaluations were reported in draft environmental assessments (EAs), which were issued for public review and comment. After considering the comments received on the draft EAs, the DOE prepared the final EAs.

On the basis of the evaluations reported in this EA, the DOE has found that the Yucca Mountain site is not disqualified under the guidelines. The DOE has also found that it is suitable for site characterization because the evidence does not support a conclusion that the site will not be able to meet each of the qualifying conditions specified in the guidelines. On the basis of these findings, the DOE is nominating the Yucca Mountain site as one of five sites suitable for characterization. 
FOREWORD . . ............................

ABSTRACT . . . . . . . . . . . . . . . . . . . . v v

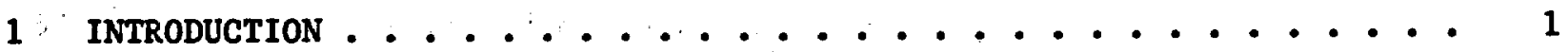

2 DECISION PROCESS AND PRELIMINARY CONCLUSIONS . . . . . . . . . . . 4

2.1 Decision process . . . . . . . . . . . . . . . . . 4

2.2 Preliminary findings and determinations . . . . . . . . . 5

2.2.1 Evaluation against the disqualifying conditions. . . . . 5

2.2.2 Grouping of sites by geohydrologic setting . . . . . . . . 5

2.2.3 Selection of the preferred site in the
Great Basin . . . . . . . . . . . . . . 6

2.2.4 Suitability of the Yucca Mountain site for development as a repository ............... 6

2.2.5 Suitability of the Yucca Mountain site for

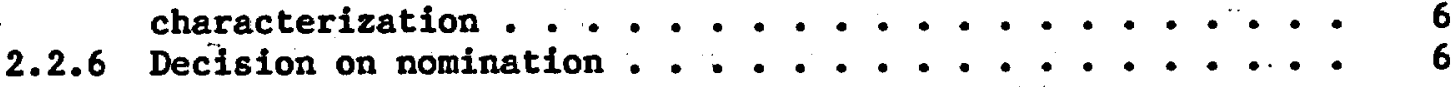

$3 \quad \operatorname{THE} \operatorname{sITE} . . . . . . . . . . . . . . . . . . . .47$

4. EFFECTS OF SITE CHARACTERIZATION . . . . . . . . . . . . . 11

5 REGIONAL AND LOCAL EFFECTS OF REPOSITORY DEVELOPMENT . . . . . . . 13

6 EVALUATIONS OF SITE SUITABILITY. . . . . . . . . . . . . . 16

6.1 The structure of the guidelines ............... 16

6.2 Summary of site evaluations against the postclosure

guidelines. . . . . . . . . . . . . . . 17

6.3 Summary of site evaluations against the preclosure

guidelines. . .......................... 18

6.3.1 Radiological safety. . . . . ............. 18

6.3.2 Environment, socioeconomics, and transportation. . . . 19

6.3.3 Ease and cost of siting, construction, operation
and closure. . . . . . . . . . . . . 19

7 Comparative evaluation of nominated sites . . . . . . . . . . . 20

7.1 Introduction ....................... . . . . . 20

7.1.1 Purpose and requirements . . . . . . . . . . . 20

7.1.2 Approach and organization ............... 20

7.1.2.1 Technical guidelines ............. 21

7.1.2.2 System guidelines ............... 21

7.2 Comparison of the sites on the basis of postclosure

guidelines ........................ 22

7.2.1 Technical guidelines . . . . . . . . . . . . . 22

7.2.1.1 Geohydrology ................. 22

7.2.1.2 Geochemistry ................. 23

7.2.1.3 Rock characteristics (postclosure) ....... 24

7.2.1.4 Climatic changes ............... 24

7.2.1.5 Erosion............... 25 
TABLE OF CONTENTS (Continued)

Page

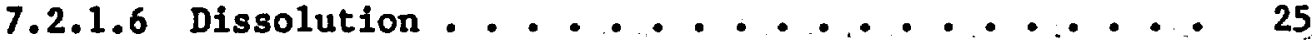

7.2.1.7 Tectonics (postclosure)........ 25

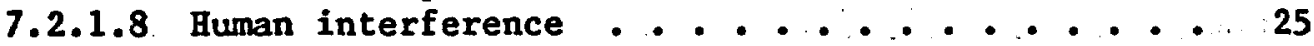

7.2.1.8.1 Natural resources ........ 25

7.2.1.8.2, Site ownership and control ..... 26

7.2.2 Postclosure system guideline . . . . . . . . . 26

7.3 Comparison of sites on the basis of preclosure guidelines . . . . 28

7.3.1 Preclosure radiological safety . . . . . . . . . 28

7.3.1.1 Technical guidelines . . . . . . . . . 28

7.3.1.1.1 Population density and

distribution ........... 28

7.3.1.1.2. Site ownership and control ..... 28

7.3.1.1.3 Meteorology .......... 29

7.3.1.1.4 Offsite installations and

operations.......... 29

7.3.1.2 Preclosure system guideline for radiological

safety ................. . 30

7.3.2 Environment, socioeconomics, and transportation . . . . 30

7.3.2.1 Technical guidelines ............ 30

7.3.2.1.1 Environmental quality . ...... 30

7.3.2.1.2 Socioeconomics impacts . . . . . 31

7.3.2.1.3 Transportation . . . . . . . 32

7.3.2.2 System guideline on environment, socioeconomics, and transportation ....... 33

7.3.3 Ease and cost of siting, construction, operation

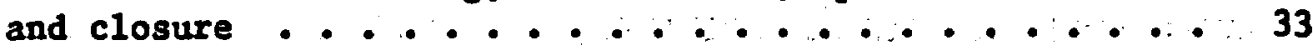

7.3.3.1 Technical guidelines . . . . . . . 33

7.3.3.1.1 Surface characteristics ....... 34

$\mathbf{P}$

7.3.3.1.2 . Rock characteristics (preclosure).... 34

7.3.3.1.3 Bydrology ........... 35

7.3.3.1.4 Tectonics (preclosure) ......... 35

7.3.3.2 System guideline on the ease and cost of

siting, construction, operation, and closure . . 36 


\section{LIST OF FIGURES}

Figure

1

2

3
Title

Fage

Potentially acceptable sites for the first repository . . . 2

Yucca Mountain site in southern Nevada . . . . . . . 8

Geologic cross section of the Yucca Mountain site . . . . . 9

$\infty$

$\infty$

$\nabla$

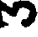

a

-ix- 


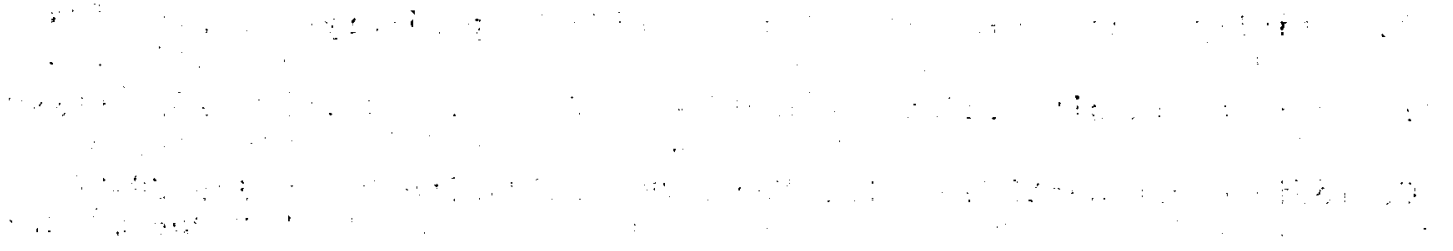


OVERVIEW .

\section{INTRODUCTION}

By the end of this century, the United States plans to begin operating the first geologic repository for the permanent disposal of commercial spent nuclear fuel and high-level radioactive waste. Public Law 97-425, the Nuclear Waste Policy Act of 1982 (the Act), specifies the process for selecting a repository site, and constructing, operating, closing, and decomissioning the repository. Congress approved geologic disposal by declaring that one of the key purposes of the Act is "to establish a schedule for the siting, construction, and operation of repositories that will provide reasonable assurance that the public and the environment will be adequately protected from the hazards posed by high-level radioactive waste and such spent nuclear fuel as may be disposed of in a repository" [Section 111(b)(1)].

A geologic repository can be viewed as a large underground mine with a complex of tunnels occupying roughly 2,000 acres at a depth between 1,000 and 4,000 feet. To handle the waste received for disposal, surface facilities will be developed which will occupy about 400 acres. The repository will be operational for about 25 to 30 years. After the repository is closed and sealed, waste isolation will be achieved by a system of multiple barriers, both natural and engineered, that will act together to contain and isolate the waste as required by regulations. The natural barriers include the geologic, hydrologic, and geochemical environment of the site. The engineered barriers consist of the waste package and the underground facility. The waste package includes the waste form, the waste disposal container, and materials placed over and around the containers. The underground facility consists of underground openings and backfill materials, not associated with the waste package, that are used to further limit ground-water circulation around the waste packages and to impede the subsequent. transport of radionuclides into the environment.

In February 1983, the DOE carried out the first requirement of the Act by formally identifying nine sites in the following locations as potentially acceptable sites for the first repository (the host rock of each site is noted in parentheses):

1. Vacherie dome, Louisiana (domal salt)

2. Cypress Creek dome, Mississippi (domal salt)

3. Richton dome, Mississippi (domal salt)

4. Yucca Mountain, Nevada (welded tuff)

5. Deaf Smith County, Texas (bedded salt)

6. Swisher County, Texas (bedded salt)

7. Davis Canyon, Utah (bedded salt)

8. Lavender Canyon, Utah (bedded salt)

9. Reference repository location, Hanford Site, Washington (basalt flows).

The locations of these sites are shown in Figure 1. 


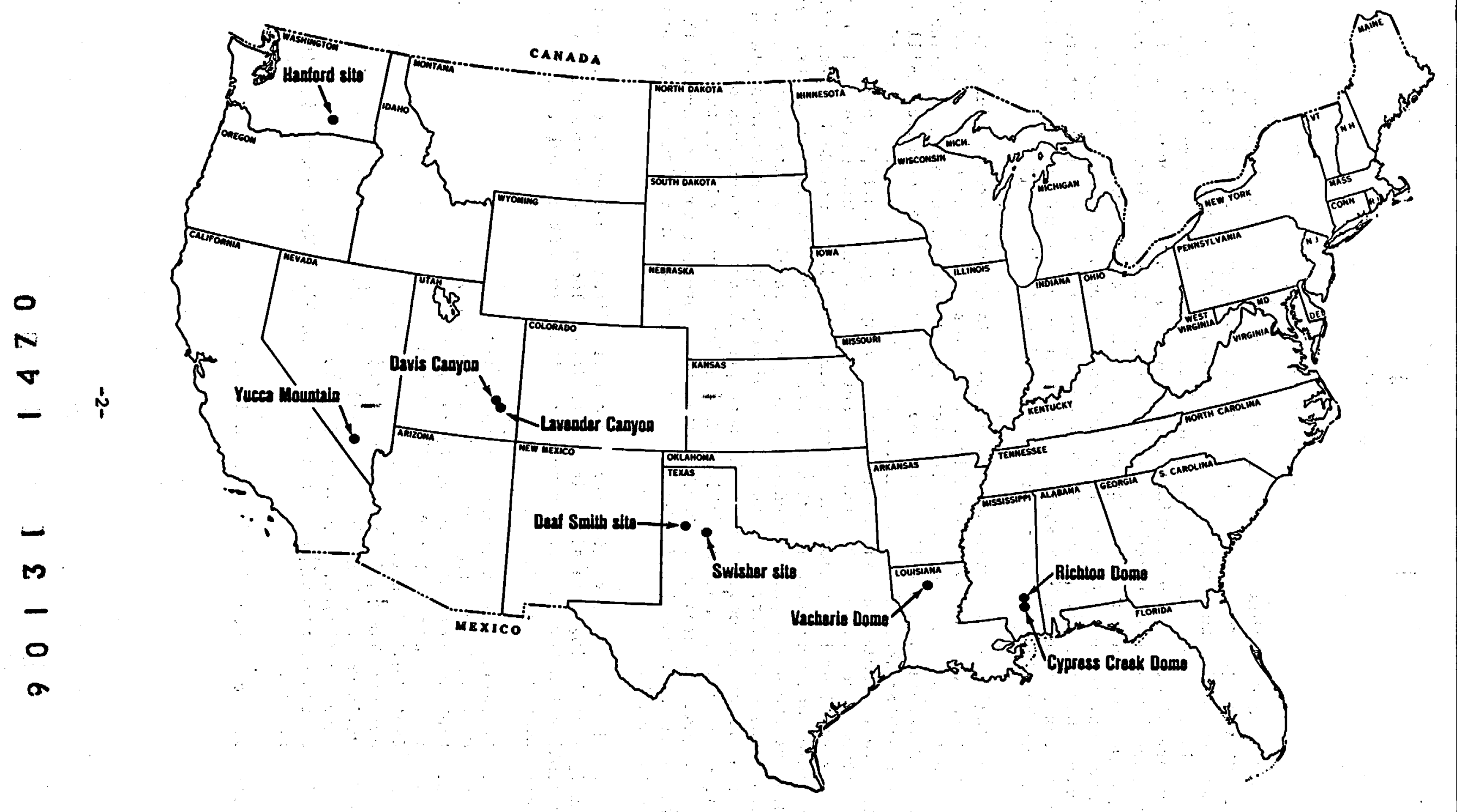

Figure 1. Potentially acceptable sites for the first repository. 
After identifying these potentially acceptable sites, the DOE published draft General Guidelines for the Recommendation of Sites for Nuclear Waste Repositories (the guidelines) in accordance with the Act. The draft guidelines were revised in response to extensive comments and received the concurrence of the Nuclear Regulatory Commission (NRC) in June 1984. Final guidelines were published in December 1984 as 10 CFR Part 960.

The Act requires the DOE to nominate at least five sites as suitable for site characterization-a formal information-gathering process that will include the sinking of one or more shafts at the site and a series of experiments and studies underground. The DOE must then recommend not fewer than three of those sites for characterization as candidate sites for the first repository. After site characterization is complete, one of the characterized sites will be recommended for development as a repository.

The Act also requires the DOE to prepare environmental assessments (EAs) to serve as the basis for site-nomination decisions. These EAs contain the following information and evaluations consistent with the requirements of Section 112 of the Act:

- A description of the decision process by which the site is being considered for nomination (EA chapters 1 and 2).

- A description of the site and its surroundings (EA Chapter 3 ).

- An evaluation of the effects of site characterization activities on public health and safety and the environment and a discussion of alternative activities that may be taken to avoid such effects (EA Chapter 4).

- An assessment of the regional and local effects of locating the proposed repository at the site (EA Chapter 5).

- An evaluation as to whether the site is suitable for site characterization (EA Chapter 6).

- An evaluation as to whether the site is suitable for development as a repository (EA Chàpter 6 ).

- A reasonable comparative evaluation of the site with other sites that have been considered (EA Chapter 7).

This overview highlights the important information and evaluations found in the EA for Yucca Mountain. Section 2 of this overview presents a summary of the decision process and findings leading to the nomination of the Yucca Mountain site. Sections 3 through 7 sumarize the results of evaluations contained in corresponding chapters in the EA. 


\section{DECISION PROCESS AND PRELIMINARY CONCLUSIONS}

\subsection{DECISION PROCESS}

The guidelines require the DOE to implement the following seven-part evaluation and decision process for nominating and recommending sites for characterization:

1. Evaluate the potentially acceptable sites against the disqualifying conditions specified in the guidelines.

2. Group all potentially acceptable sites according to their geohydrologic settings.

3. For those geohydrologic settings that contain more than one potentially acceptable site, select the preferred site on the basis of a comparative evaluation of all potentially acceptable sites in the setting.

4. Evaluate each preferred site within a geohydrologic setting and decide whether such site is suitable for the development of a repository under the qualifying condition of each applicable guideline.

5. Evaluate each preferred site within a geohydrologic setting and decide whether such site is suitable for site characterization under the qualifying condition of each applicable guideline.

6. Perform a reasonable comparative evaluation under each guideline of the sites proposed for nomination.

7. Consider an order of preference of the nominated sites as recommended sites and, on the basis of this order of preference, recomend not fewer than three sites for characterization to the President.

The DOE prepared a draft EA for each of the nine potentially acceptable sites to give all interested parties an opportunity to review the full evaluation of all sites considered. In preparing the final EAs for the five nominated sites, the DOE considered all comments that were received.

With the issuance of the final EAs, the DOE will formally nominate five sites as suitable for characterization. The Secretary of Energy will then recommend not fewer than three of these sites to the President as candidate. sites for characterization. After the President approves the Secretary's recommendation, characterization activities will begin at those sites. After characterization is completed, the DOE will again evaluate each site against the guidelines and, after completing an environmental impact statement, will recomend one site to the President for the first repository. The President may then recommend the site to Congress. At this point, the host state may issue a notice of disapproval that can be overridden only by a joint resolution of both Houses of the U.S. Congress. If the notice of disapproval 
is not overridden, the President must submit another repository site recommendation with 12 months. If no notice of disapproval is submitted, or if Congress overrides the notice of disapproval, then the site designation is effective, and the DOE will file an application with the NRC to obtain a construction authorization for a repository at that site.

\subsection{PRELIMINARY FINDINGS AND DETERMINATIONS}

Summarized below are the DOE's preliminary findings and determinations that apply to the Yucca Mountain site.

\subsubsection{EVALUATION AGAINST THE DISQUALIFYING CONDITIONS}

The evidence does not support the disqualification of the Yucca Mountain site under. the guidelines; nor are any of the other eight potentially acceptable sites found to be disqualified.

\subsubsection{GROUPING OF SITES BY GEOHYDROLOGIC SETTING}

The nine potentially acceptable sites are contained within five distinct geohydrologic settings as defined by the U.S. Geological Survey. The sites are grouped by the DOE' 5 geohydrologic designations as follows:

Geohydrologic setting

Columbia Plateau

Great Basin

Permian Basin

Paradox Basin

Gulf Interior Region of the Gulf Coastal Plain

\section{Site}

Reference repository location, Hanford Site, Washington

Yucca Mountain, Nevada

Deaf Smith County and Swisher County, Texas

Lavender Canyon and Davis Canyon, Utah

Vacherie Dome, Louisiana; Cypress Creek Dome and Richton Dome, Mississippi

The Yucca Mountain site is hydrologically distinct from the other sites. The proposed repository horizon at the site is in the unsaturated zone about 200 to 400 meters (656 to 1,300 feet) above the water table. The proposed horizons at the other eight sites are all situated well below the water table. 


\subsubsection{SELECTION OF THE PREFERRED SITE IN THE GREAT BASIN}

The Yucca Mountain site is the only potentially acceptable site identified in the Great Basin. The process by which it was identified as the preferred site in that setting is described in Chapter 2 of the Yucca Mountain EA.

\subsubsection{SUITABILITY OF THE YUCCA MOUNTAIN SITE FOR DEVELOPMENT AS A REPOSITORY}

Section 112(b) of the Act requires the DOE to evaluate the suitability of a site for development as a repository under each guideline that does not require site characterization as a prerequisite for the application of such guideline. The intent is to preclude the investment of money and effort in sites that could be disqualified under those guidelines for which substantial information is available for site evaluations. The guidelines that do not require characterization address mainly those characteristics of a site that are related to the effects of a repository on public health and safety, the quality of the environment, and socioeconomic conditions during the operating period, before the repository is closed and sealed.

For a site to be suitable for repository development under each of those guidelines that do not require site characterization, no disqualifying conditions can be present, and each of the qualifying conditions must be met. A final determination of suitability for repository development cannot be made until site characterization 1s complete. However, at this stage, the evidence does not support a finding that the Yucca Mountain site is disqualified. Furthermore, the evidence does not support a finding that the Yucca Mountain site is not likely to meet all the qualifying conditions under those. guidelines that do not require site characterization.

\subsubsection{SUITABILITY OF THE YUCCA MOUNTAIN SITE FOR CHARACTERIZATION}

To determine whether a site is suitable for characterization, the DOE: must evaluate the site against all the guidelines, including those that require site characterization. To judge that a site is suitable, the DOE must conclude that the evidence does not support a finding that the site is not likely to meet all of the guidelines. The evaluations against the guidelines have led to a preliminary conclusion that the Yucca Mountain site is suitable for characterization.

\subsubsection{PRELIMINARY DECISION ON NOMINATION}

Having made the above findings, the DOE has decided to nominate the Yucca Mountain site as suitable for characterization. . The other potentially acceptable sites selected for nomination are Davis Canyon, Utah; Deaf Smith, Texas; the reference repository location at the Hanford site, Washington; and the Richton dome, Mississippi. 
The Yucca Mountain site is in Nye County, Nevada, on and adjacent to the southwest portion of the Nevada Test Site, about 137 kilometers ( 85 miles) by air northwest of Las Vegas (Figure 2). The Yucca Mountain site is on three adjacent parcels of Federal land, each under the separate control of the DOE, the U.S. Air Force, and the Bureau of Land Management.

Yucca Mountain is in the southern part of the Great Basin, a part of the Basin and Range Physiographic Province in which all surface waters drain into closed basins rather than flowing into the ocean. As shown in Figure 3 , the rocks in this province can be divided into four groups in order of decreasing geologic age: (1) Precambrian crystalline basement rocks; (2) Upper Precambrian and Paleozoic sedimentary rocks that have been folded, faulted, and uplifed to form large mountain ranges that eventually eroded to a gentle plain; (3) Tertiary tuffaceous volcanic material such as that which forms Yucca Mountain; and (4) alluvium derived from the erosion of the surrounding mountains. The tuffaceous rocks occur in layers at least 2,000 meters $(6,500$ feet $)$ thick.

Faulting and volcanism that produced the early features of the Basin and Range Province took place concurrently approximately 10 to 40 million years ago. In the vicinity of Yucca Mountain, tectonic activity has steadily decreased over the last 10 million years. Minor volcanic activity has continued during basin filling and, most recently, produced thin, areally restricted flows and cones of basaltic material on Crater Flat, west of Yucca Mountain. Some faults in the vicinity of Yucca Mountain show evidence of continued movement during the last 2 million years. Investigations to date covering an 1,100 square-kilometer (425 square-mile) area around the site have found thirty-two faults that of $f$ set or fracture Quaternary deposits. Quaternary faults have been divided into three broad age groups: 5 faults last moved between 270,000 and 40,000 years ago; 4 other faults last moved about 1 million years ago; and 23 faults last moved probably between 2 million and 1.2 million years ago. Recently available but unevaluated thermoluminescence dates may indicate on the order of 1 to 10 centimeters $(2.54$ to 25.4 inches) of fault displacement in eastern Crater Flat less than 6,000 years ago. Yucca Mountain and areas to the west and south have had a relatively low level of seismicity throughout the historical record.

The hydrologic system of the southern part of the Great Basin is characterized by low precipitation, deep water tables, and closed topographic and ground-water basins that contain all surface-water flow within the region. Ground water is recharged by the slow infiltration and percolation of rain and surface water through intergranular pores and perhaps through fractures in the rocks overlying the water table. At Yucca Mountain, most of the annual precipitation of 150 millimeters (5.91 inches) is returned to the atmosphere through evaporation and plant transpiration before it can infiltrate deep enough to become percolation and finally ground-water recharge. Only a small fraction ( 3 percent or less) of the annual precipitation reaches the depth proposed for the repository.

At Yucca Mountain, a repository would be constructed in the unsaturated zone 200 to 400 meters (656 to 1,300 feet) above the water table. The movement of ground water in the unsaturated zone is typified by a very low 


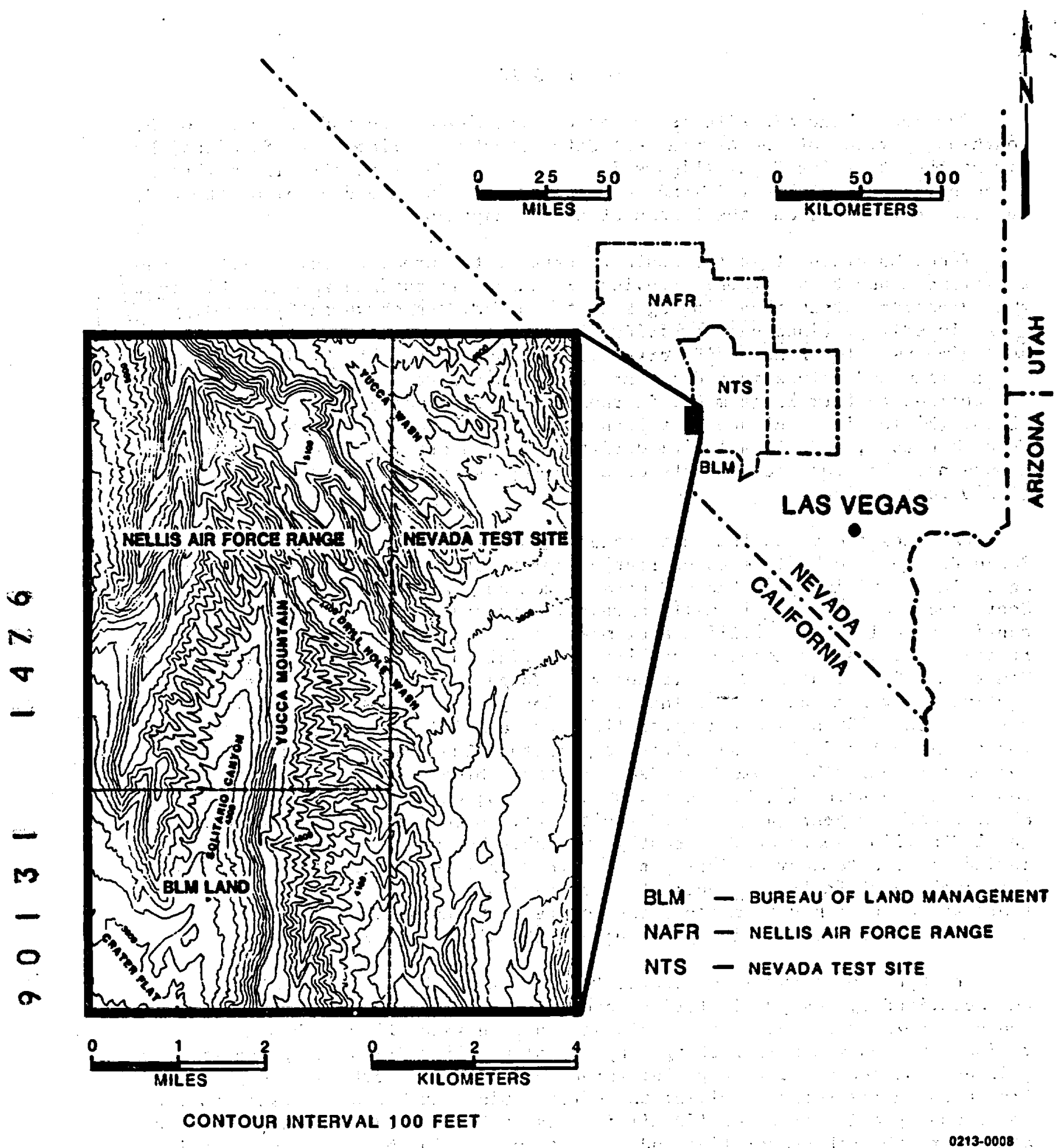

Figure 2. Yucca Mountain site in southern Nevada. 
$N$

$N$

$\nabla$

$-$

$m$

$\rightarrow$

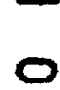

o.

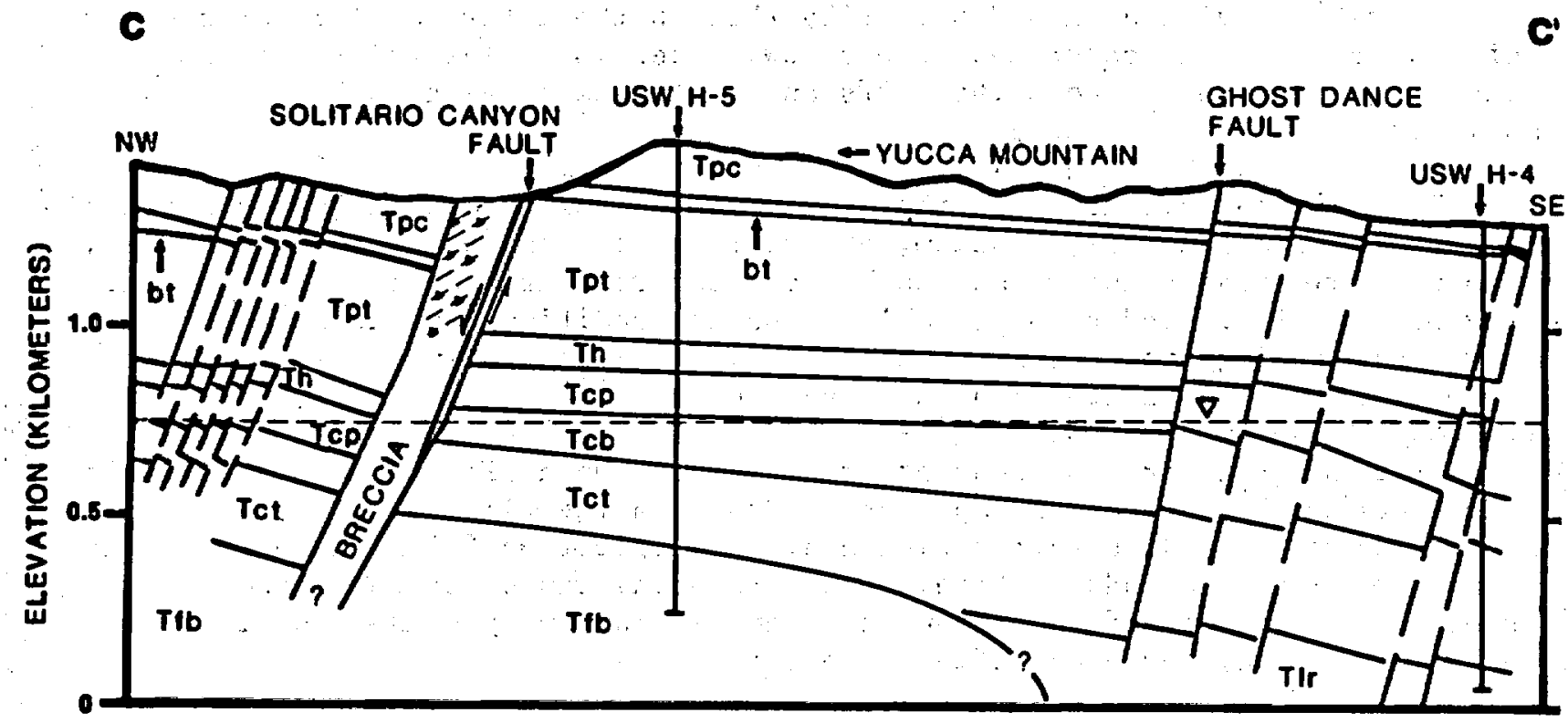

TPC TIVA CANYOON MEMBER

bI BEDDED TUFF

TPI TOPOPAH SPRING MEMBER

Th TUFFACEOUS BEDS OF CALICO HILLS

TCD PROW PASS MEMBER

TCb BULLFROG MEMBER

TCt TAAM MEMBER

TII LITHIC RIDGE MEMBER

TIO FLOW BRECCIA

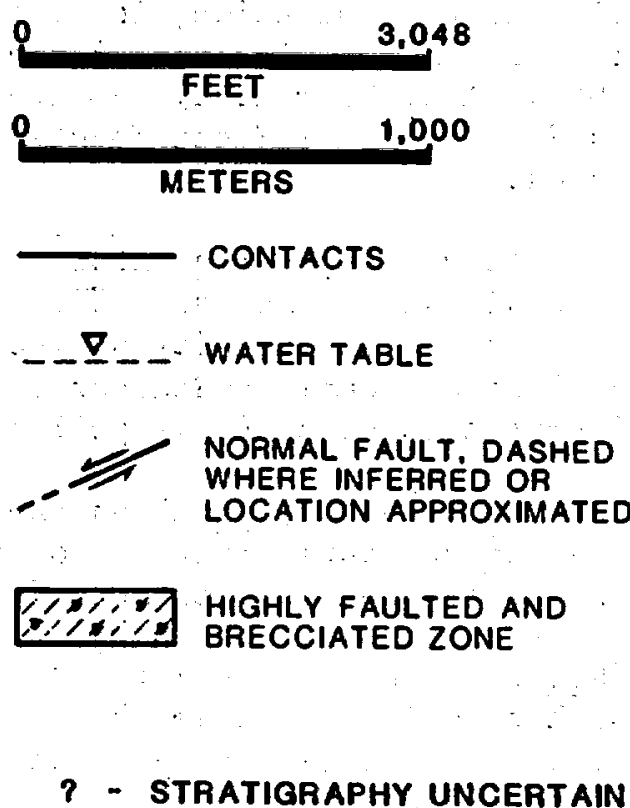

Figure 3. Geologic cross section of the Yucca Mountain site.

0213-0008 
flux of water moving downward primarily through the intergranular pores of the tuff layers. In the saturated zone below, water moves laterally through fractures and pores in both the tuffs and in the underlying carbonate-rock aquifers.

There is no evidence that the Yucca Mountain site contains any commercially attractive geothermal, uranium, hydrocarbon, oil shale, or coal resources, although low-grade uranium and geothermal resources are found in the general area of the site. Under foreseeable economic conditions and in spite of the: many small mining operations in the area, there is no potential at the site for extracting the limited mineral resources.

No perennial streams occur at or near Yucca Mountain. The only reliable sources of surface water are springs in Oasis Valley, Amargosa Desert, and Death Valley. Rapid run-off during heavy precipitation fills the normally dry washes for brief periods of time. Local flooding can occur where the water exceeds the capacity of the channels. The terminal playas may contain standing water for days or weeks after severe storms.

The climate at Yucca Mountain is characterized by high solar insolation, limited precipitation, low relative humidity, and large diurnal temperature ranges. Meteorological data have been collected at the Nevada Test Site since 1956. Average monthly temperatures at Yucca Flat vary from $1.8^{\circ} \mathrm{C}\left(35.3^{\circ} \mathrm{F}\right)$ to $24.8^{\circ} \mathrm{C}\left(76.6^{\circ} \mathrm{F}\right)$; Yucca Mountain is expected to have slightly lower temperatures.

No site-specific information about air quality is available for the Yucca Mountain site. However, data from similar remote desert areas suggest that, the ambient air quality at Yucca Mountain probably surpasses the National Ambient Air Quality Standards. Suspended particulates are probably the most important source of air pollution at Yucca Mountain.

No plant or animal on the Nevada Test Site or in the proposed repository area is currently. 1isted, nor is one an official candidate for 1 isting, under the Endangered Species Act of 1973. Therefore, there are no areas designated as critical habitats in the repository area. The Mojave fishhook cactus (Sclerocactus polyancistrus) and the desert tortoise (Gopherus agassizii), both of which occur in the repository area, are under consideration for Federal protection as endangered species. The desert tortoise is a Stateprotected species.

Literature reviews and field surveys of the archaeological, cultural, and historical resources of Yucca Mountain and its vicinity have led to the identification of 178 prehistoric aboriginal sites. These sites are evidence that the area of Yucca Mountain was used by small and highly mobile groups or bands of aboriginal hunter-gatherers.

Social and economic impacts are expected to occur in areas where repository-related expenditures would be made and where the inmigrating repositoryrelated work force would reside. Historical settlement patterns of workers at the Nevada Test Site (NTS), located in Nye County, provide a reasonable indication of where repository workers and their families would settle. Data on recent settlement patterns of these workers indicate that most (96 percent) of the repository-related population would likely settle in Nye and Clark 
counties. Therefore, the areas expected to experience socioeconomic effects consist of Nye County, where the site is located, and neighboring Clark County.

Nye County is largely rural, with a population density of 0.5 person per square mile. The three unincorporated towns in southern Nye County closest to the proposed site are Amargosa Valley, Beatty, and Pahrump. The total population of Nye County in 1980 was 9,048 .

The 1980 population of Clark County was 463,087, with a density of 58.8 persons per square mile. Approximately 96 percent of this population resides in the Las Vegas valley. Incorporated cities in the Las Vegas valley include Henderson, Las Vegas, and North Las Vegas. Unincorporated towns and communities in the Las Vegas valley are East Las Vegas, Enterprise, Grandview, Lone Mountain, Paradise, Spring Valley, Sunrise Manor, and Winchester.

\section{EFFECTS OF SITE CHARACTERIZATION}

To obtain the information necessary for evaluating the suitability of the Yucca Mountain site for a repository, the DOE will conduct a site characterization program of underground testing. To carry out this program; the DOE will construct two shafts (one shaft for exploration and one for emergency egress), excavate drifts at the proposed repository depth, and construct support structures on the surface. In addition to the tests performed underground and in the exploratory shaft, geologic field studies will be conducted to characterize underground conditions. This site characterization program will require the clearing of about 285 hectares ( 705 acres) of 1 and.

Concurrent with geologic site characterization activities, the DOE will study the environment of the site and its vicinity, including weather conditions, air quality, noise, plant and animal communities, and archaeological and cultural resources.' Social and economic conditions will also be investigated in the area expected to be affected by the repository.

The site characterization program will last several years. At the end of this period, if the site is found to be unsuitable for a repository, the exploratory shaft facility would be either decommissioned or preserved for other uses. Decomissioning could include the backfilling and sealing of the underground openings and shafts, and restoration of the surface area.

Site characterization activities; are expected to result in minimal localized environmental effects on geologic and hydrologic conditions; land use; surface soils; ecosystems; air quality; noise levels; aesthetic quality; and cultural, historical, and archaeological resources. However, some potentially adverse effects that would result from site characterization have been identified.

One adverse impact of site characterization would be the effects on wildlife populations resulting from the removal of wildlife habitat. Approximately 285 hectares ( 705 acres) of habitat would be disturbed by drill pads, roads, utility lines, trenches, seismic lines, off-road driving, and construction. Wildlife in the surrounding areas could also be disturbed by human presence and activity. In addition, some roadkills are expected. Measures 
will be taken to mitigate adverse effects. For example, sensitive areas, such as habitats. for the Mojave fishhook cactus, could be avoided. Reclamation of the disturbed lands would be undertaken. However, because the site and its immediate surroundings do not support any ecologically unique communities and because the area to be cleared is small compared to the tens of thousands of acres of relatively undisturbed desert surrounding Yucca Mountain, the ecological effects on a regional level will be minimal.

Adverse effects on air quality may result from the particulate and gaseous emissions from construction and operation of the exploratory shaft and concomitant site characterization activities. Because Yucca Mountain is in an area where the existing air quality is considered to be better than State and Federal ambient air-quality standards, site characterization would be subject to regulations designed to prevent a significant deterioration of the ambient air quality.

The effect of noise is expected to be insignificant on a regional level. Analyses indicate that wildlife may be affected within 0.6 kilometer ( $0.4 \mathrm{mile}$ ) of the exploratory shaft construction site and within $1.5 \mathrm{kilo}-$ meters ( 1 mile) of a surface blast site. No wildlife impacts are expected from underground blasting or from operation of the exploratory shaft facility. The potential effects of noise on wildlife is speculative and based on laboratory experiments. Residents of the nearest town (Amargosa Valley) are: not expected to be adversely affected by noise produced by site characterization activities.

Because of site-characterization activities and increased human activities in the area, there is a potential for unauthorized nonscientific excavation of archaeological sites or the collection of artifacts. To mitigate this effect, sensitive sites will be identified in cultural-resource surveys and avoided or protected where possible., An archaeologist will supervise the collection of artifacts in the areas directly affected by site-characterization activities and where sites cannot be avolded or adequately protected. Four significant sites have been identified. Systematic collections of the cultural remains at the sites have been completed to mitigate the potential adverse impact of site characterization.

The social and economic impacts of site characterization are expected to be small and insignificant. Some social effects may result from an increase in public awareness of the repository project. Selection of Yucca Mountain for site characterization could induce changes in social organization associated with the formation of support and opposition groups, disputes within existing groups, and focusing of attention on repository-related issues.

A potentially significant fiscal effect of recommending Yucca Mountain for site characterization would be an increase in the state and local. participation in planning activities. However, the Act explicitly recognizes the fiscal implications of State participation and provides a mechanism for financial assistance. 


\section{REGIONAL AND LOCAL EFFECTS OF REPOSITORY DEVELOPMENT}

To determine the effects of developing a two-stage repository at Yucca Mountain, three periods of repository development were examined: (1) construction, (2) operations, and (3) decommissioning and closure.

All of the Stage 1 and a portion of the Stage 2 facilities would be constructed and some of the subsurface facilities would be excavated during the first $4: 3$ years of the 7-year construction period. The Stage 2 facilities would be completed in the last 3 years of the construction period, which would overlap with the first 3 years of the operations period. The operations period, which would last for 50 years, would consist of two phases. Radioactive waste would be received and emplaced during the 28-year emplacement phase. The underground facilities and surrounding environment would be monitored during this phase. The 22-year caretaker phase would follow completion of waste-emplacement operations; the facilities, as well as the surrounding environment, would continue to be monitored, and the retrievability option would be maintained in compliance with NRC requirements (10 CFR Part 60,1983 ) for ensuring retrievability at any time up to 50 years af ter waste emplacement begins. If a decision to retrieve the waste were made during the caretaker phase, the lifetime of the project would be extended approximately 30 years during which actual waste retrieval would be accomplished. A decision to close and decommission the repository could be made at any time during the caretaker phase. The decommissioning and closing of the repository would last for an 8-year period under the vertical-emplacement alternative or a 3-year period under the horizontal-emplacement alternative. During closure and decommissioning, shafts and boreholes would be closed and sealed, land-use controls would be instituted, the surface facilities would be decontaminated and decomissioned, and permanent markers or monuments would be erected at the site to warn.future generations about the presence of the underground repository.

Both beneficial and adverse effects could result from development of a repository at Yucca Mountain. Locating a repository at Yucca Mountain is expected to have minimal impact on the geologic environment, the hydrologic environment, and land use.

Possible adverse effects on ecosystems are greatest for the construction period, and are a result of removing vegetation and increasing transportation in the vicinity of the site. The primary ecological effect would be the removal of approximately. 680 hectares (1,680 acres) of vegetation. Clearing this land is not expected to be ecologically significant because the affected areas are very small compared to the surrounding undisturbed areas of similar vegetation.

Indirect ecological effects of construction may also be caused by combustion emissions, fugitive dust, sedimentation, and noise.

The potentially adverse effects on ambient air quality would be due largely to the particulates generated by site clearing, construction activities, traffic, and wind erosion. The projected concentrations of the combustion emissions are not considered high enough to cause any significant adverse effects to the plants and animals in the region. However, fugitive dust deposition on the leaves of desert shrubs can increase the loss of leaves 
and the death of shrubby vegetation near disturbed areas. Mitigative measures, such as wetting the surfaces of disturbed areas, can be used to minimize fugitive dust. Ambient levels of regulated pollutants are expected to be below State and Federal standards for ambient air quality; however; a more precise determination of air-quality effects and the measures that can be taken to reduce them will be made during site characterization.

Repository workers, who are protected by worker safety regulations, and wildlife are the only sensitive noise receptors in the vicinity of Yucca Mountain. The effects of noise on wildlife are speculative. . No significant noise effects are expected, but any impacts to wildlife should be limited to the immediate vicinity of the site during construction, U.S. Highway 95 during transportation of men and materials to the site, and in the vicinity of the repository during operations. Noise from rail transport could affect humans at Indian Springs, Floyd R. Lamb State Park, and Mercury. No significant impacts are expected in Amargosa Valley or Indian Springs from road traffic.

The construction and operation of the repository may lead to the physical disturbance of archaeological sites and possibly the loss of data that are crucial for interpreting these sites. Several mitigating measures would be used to protect known sites where such impacts could occur; for example, fences could be erected around significant sites and a professional archaeologist could be employed to monitor construction within sensitive locations.

Transportation effects would result from increased commuter traffic and the hauling of supplies and radioactive waste:- Radiological risks would result from the direct external radiation emitted by the radioactive waste as a shipment is transported. Nonradiological risks are traffic accidents and the health effects that result from the pollutants emitted by combustion engines; they would occur regardless of the cargo carried by the railcar or truck. In general, both types of risk will vary with the distance traveled and with the mode of transportation (road or rail).

Transportation accidents severe enough to release radioactive materials from a shipping container are extremely unlikely. On a national basis, the radiological impacts associated with truck shipment are much greater than those for rail, and the use of a monitored retrievable storage (MRS) facility would reduce the total radiological impact of transporting nuclear wastes, especially if rail is used as a shipping mode between the waste generation point and the MRS. As in the case of national impacts, the radiological risk on a regional basis from truck shipment is significantly greater than for rail shipment, but the risk of transporting nuclear waste within the state of Nevada is very low regardless of the mode of shipment: or the use of an MRS facility.

Certain nonradiological risks are inherent in any large-scale transportation program, regardless of whether nuclear materials are involved or not. Nonradiological effects include the potential induction of cancer by nonradioactive pollutants emitted by the truck or train and the fatalities or injuries resulting from railcar or truck accidents. On a national scale the results follow the same general pattern as that of radiological impacts when waste is shipped directly to the repository in that truck shipments represent a greater risk than do rail shipments. The difference in nonradiological risk between shipping modes is significantly reduced if an MRS facility is assumed. For 
the regional case involving no MRS, the total nonradiological risk is low; the risk associated with truck shipments is greater than that for train shipments; and the largest fraction of the risk for truck shipments is incurred along the Interstate 15 southbound route. If an MRS facility is assumed, the total nonradiological risk also is low and the risk associated with train shipment is greater than that for truck shipment.

Total national risk is a function of the number of shipments made and whether an MRS facility is used in the waste-management system. In all cases nonradiological fatalities and injuries far exceed those due to the radiological nature of the cargo. The four scenarios are ranked according to risk in the following manner, with the highest risk first:

1. Truck transport of spent fuel to an MRS facllity with a dedicated train from the MRS facility to Yucca Mountain.

2. Direct truck transport to Yucca Mountain.

3. Rail transport of spent fuel to an MRS facility with a dedicated train from the MRS facility to Yucca Mountain.

4. Direct rail transport to Yucca Mountain.

From a regional standpoint the safest scenario is direct transport from origin to Yucca Mountain by rail. The highest risk is associated with direct transport of western fuel from origin to Yucca Mountain by truck with eastern fuel being transported from the MRS facility by dedicated rail. However, as previously noted, all scenarios produce extremely low risk within the State of Nevada.

Access routes would be relatively easy to construct at the Yucca Mountain site and would traverse flat terrain, thereby reducing the risk of accidents. These routes would also bypass local towns and communities, providing direct access to regional and national transportation networks.

Total employment (direct plus indirect) induced by the project would increase and decrease over time in relation to the size of the direct project work force. Total annual employment would reach a peak of about 4,800 jobs in 1998. Near the end of the construction period in 1999, this number would decline to about 4,150. The average level of total employment would be about 4,260 for the 25-year emplacement phase through 2024. 'Labor market impacts would depend upon the local and regional availability of workers at various phases of the project, particularly during the construction period (from 1993 through 2000) when direct work force requirements would reach their peak. Labor market impacts could include inmigration of workers having mining and construction ski1ls and an increase in wages and salaries to induce these workers to relocate to the area. Peak annual direct and indirect wage expenditures are expected to be between $\$ 95.37$ and $\$ 110.04$ million dollars during the overlap of the construction and operations periods. Additional revenues would result from local repository-related purchases.

During peak employment in 1998, the project could cause a worst-case population increase of about 16,100 over baseline projections for the bicounty area, which is about 2 percent of the baseline bicounty population. If direct 
and indirect workers follow the settlement patterns of workers recent1y employed by the $\mathrm{DOB}$ and its contractors at the Nevada Test Site, Clark County would receive 83 percent of the maximum annual project-related population increase or a maximum of about 13,940 people. Nye County, which would receive about 13 percent of the total, would experience a maximum influx of about 2,180 people.

Potential community-service impacts would be mainly on county-wide service providers that are more likely to. have the resources for managing growth than are the unincorporated towns of Nye and Clark counties. However, available information on the current adequacy of community services indicates that repository-related population growth in the sparsely populated areas of Nye and Clark counties could contribute to existing community service supply problems in some communities. These problems would be small in urban areas of clark County. The specific details of the effects on community services and net government revenues are not certain at this time; however, the Act provides for mitigation assistance where needed.

In Nye County, the maximum service requirements increase over those projected for the future baseline would be about 5 percent in 1998. During most of the project, service requirements would be less than 4 percent higher than the projected baseline. In Clark County, it is not expected that the requirements for increased services would exceed forecast baseline service levels by more than 1.7 percent during the period of greatest impact, which is the combined construction-operations period from 1998 to 2000. In other periods, the incremental service requirements associated with the repository in Clark County would range from about 0.1 to 1.4 percent over those expected due to projected baseline growth.

\section{EVALUATIONS OF SITE. SUITABILITY}

The DOE has evaluated the Yucca Mountain site to determine its suitability as a candidate for site characterization. This evaluation was based mainly on the siting guidelines, but it was also based in part on the expected effects of site characterization and of repository development, as summarized in the preceding sections.

\subsection{THE STRUCTURE OF - THE GUIDELINES}

The guidelines are divided into two sets: postclosure (the period after the repository is permanently closed) and preclosure (the period of repository siting, construction, operation, closure, and decomissioning). The postclosure and preclosure guidelines contain both technical and system guide1ines. The technical guidelines address the specific characteristics of the site that are considered to have a bearing on preclosure and postclosure performance of the repository.: The system guidelines address the expected performance of the total system, including its engineered components; their objective is to protect public health and safety and to preserve the quality of the environment. 
The postclosure technical guidelines address the characteristics that could affect the long-term ability of the site to isolate waste from the accessible environment. In particular they cover geohydrologic conditions, geochemical conditions, rock characteristics, climatic changes, erosion, dissolution, tectonics, and human interference. The postclosure system guideline requires the site to contain and isolate waste from the accessible environment in accordance with the standards and regulations specifically promulgated for repositories by the Environmental Protection Agency (EPA) and the Nuclear Regulatory Comission (NRC). In order to achieve the specified level of containment and isolation, the site must allow for the use of engineered barriers.

The preclosure guidelines are divided into three groups: (1) preclosure radiologicai safety; (2) environment, socioeconomics, and transportation; and (3) the ease and cost of siting, construction, operation, and closure. A preclosure system guideline is specified for each of these groups. The associated technical guidelines address site suitability in terms of population density and distribution, site ownership and control, meteorology, offsite installations and operations, environmental quality, socioeconomics, transportation, surface characteristics, rock characteristics, hydrology, and tectonics.

\subsection{SUMMARY OF SITE EVALUATIONS AGAINST THE POSTCLOSURE GUIDELINES}

Features of the Yucca Mountain site that contribute to its long-term ability to isolate waste from the accessible environment include (1) an unsaturated environment, (2) the probable occurrence of zeolite minerals along the paths of ground-water flow to the accessible environment, and (3) a low potential for human intrusion.

Ground-water flow is a mechanism by which radionuclides could travel from the repository to the accessible environment after closure. The unsaturated zone at Yucca Mountain is the most significant barrier to waste migration because the amount of water available for corrosion of waste disposal containers and radionuclide transport is very limited in this zone. Furthermore, the climate of the region is very arid. The present low flux of water through the unsaturated zone is not expected to change sufficiently to compromise isolation over the next 10,000 years-the time required for waste isolation.

The occurrence of zeolite minerals along probable flow paths to the accessible environment provides a barrier to radionuclide migration because of the radionuclide-sorption capacity of zeolites. The characteristics of the probable flow paths, coupled with the characteristics of the unsaturated zone, would substantially 1 imit the movement of radionuclides.

No economic deposits of oil, gas, or mineral resources have been found at the site, and none are expected to be found. Thus, there is very little potential for inadvertent human interference to disrupt the isolation capabilities of the Yucca Mountain site.

A condition that may adversely affect the ability of the natural barriers at the site to isolate waste is the presence of oxidizing ground water. At 
Yucca Mountain, oxidizing ground water is present in the saturated zone and is expected in the unsaturated zone. The presence of oxidizing waters is of concern mainly because it may increase corrosion rates of waste disposal containers and the solubility and mobilization of radionuclides. However, because the repository would be in the unsaturated zone and thus have little exposure to ground water, the presence of oxidizing ground water may not significantly affect the lifetime of :the container or the movement of radionuclides. In addition many container materials, when exposed to oxidizing conditions, form protective coatings that would prolong the lifetime of the container.

With respect to the possibility of disruptive events that would affect repository performance, the Yucca Mountain site is in a geologic setting where earthquakes of greater magnitude than those recorded in the geologic setting could occur. However, if these events do occur, they are not expected to affect the waste-isolation capabilities of the site, because such events are not likely to alter the natural characteristics of the unsaturated zone, which is the primary mechanism for controlling radionuclide migration.

In order to meet the EPA standard for long-term waste containment and isolation, the NRC requires that the waste package provide substantially complete containment of waste for a minimum of 300 years and that, after this period of containment, the radionuclide-release rate not exceed one part in 100,000 per year of the inventory calculated to be present after 1,000 years. The lifetime of waste packages at the Yucca Mountain site is expected to be more than 3,000 gears. After the period of containment, the fractional rate of radionuclide release from the engineered-barrier system is estimated to be within the NRC regulatiory. limits. The average time of ground-water travel from the disturbed zone to the accessible environment is conservatively estimated to be 43,270 years. Preliminary assessments of engineered-barrier performance based on realistic but conservative assumptions indicate that the EPA limit on the release rate to the accessible environment would be met at the Yucca Mountain site.

\subsection{SUMMARY OF SITE EVALUATIONS AGAINST THE PRECLOSURE GUIDELINES}

The evaluations of the Yucca Mountain site against the three groups of preclosure guidelines are summarized below.

\subsubsection{RADIOLOGICAL SAFETY}

Preliminary preclosure assessments for the Yucca Mountain site indicate that radioactivity releases would not exceed any of the applicable radiation standards during repository operation and closure. In addition the site was evaluated against the four technical guidelines that address the radiological impacts of repository operation: population density and distribution, site ownership and control, meteorology, and the effects of operations and accidents at nearby installations. 
The Yucca Mountain site is on Federal lands remote from populated areas. It is about 137 kilometers ( 85 miles) by air from the Las Vegas urban area, which is the nearest population center. The population density of Nye County is only 0.5 person per square mile. As a result, it is unlikely that radioactive releases from the repository could affect large numbers of people.

The weather conditions at the site are such that an atmospheric.release of radioactive material, should a release occur, is not expected to be preferentially transported toward population centers. Also, there is little probability of operational accidents from weather and other natural phenomena.

There is little potential for the disruption of repository operations as a result of accidents at the Nevada Test Site. However, routine weapons testing at the test site would temporarily disrupt operations at the repository, because during such testing the repository workers would not be allowed to enter the underground area for safety reasons.

\subsubsection{ENVIRONMENT, SOCIOECONOMICS, AND TRANSPORTATION}

Three technical guidelines address the environmental; socioeconomic, and transportation effects of repository siting, construction, operation, closure, and decomissioning. These effects, which would be both beneficial and adverse, are summarized in sections 4 and 5 above. Preliminary analyses indicate that there are no significant adverse environmental impacts that cannot be mitigated; the socioeconomic welfare of the public can be preserved; transport of wastes can be conducted in compliance with regulations; the public and the environment will be adequately protected from the hazards posed by radioactive waste disposal.

With respect to the system guideline on the environment, socioeconomics, and transportation, the evidence does not support a finding that the Yucca Mountain site is not likely to meet the qualifying condition of protecting the public and the environment from the potential hazards of waste disposal.

\subsubsection{EASE AND COST OF SITING, CONSTRUCTION, OPERATION, AND CLOSURE}

Four technical guidelines address the ease and cost of siting, construction, operation, and closure: surface characteristics, rock characteristics, hydrology, and tectonics. The characteristics of the tuff at Yucca Mountain are favorable. For example, underground openings are expected to require minimal support, such as light rock-bolting and wire mesh. There appears to be no requirement for extensive maintenance to keep passageways open to the required dimensions. It is expected that excavated openings would remain stable enough to allow the retrieval of the waste, if necessary.

Information indicates that the current usable primary repository area at the Yucca Mountain site offers 1 imited lateral flexibility and adequate vertical flexibility for designing and constructing the repository. Additional area is available and can be added to the usable area during site characterization. The predicted peak seismicity of the site is within the 
range that allows the use of reasonably available technology for design of surface and underground repository facilities.

These preliminary evaluations indicate that the repository can be constructed and operated with reasonably available technology and that the costs would be comparable to the costs of construction a repository at the other potentially acceptable sites. Therefore, there is no evidence to support a finding that the site is not likely to meet the qualifying condition of the system guideline on the ease and cost of siting, construction, operation, and closure.

\section{COMPARATIVE EVALUATION OF NOMINATED SITES}

\subsection{INTRODUCTION}

\subsubsection{PURPOSE AND. REQUIREMENTS}

Chapter 7 presents a comparative evaluation of the five sites nominated as suitable for site characterization in order to satisfy the following:

1. Section 112(b)(1)(E)(iv) of the Nuclear Waste Policy Act of 1982 , which requires that a "reasonable comparative evaluation" be included in the environmental assessments that accompany site nomination.

2. Section 960.3-2-2-3 of the DOE's siting guidelines (10 CFR Part 960), which requires that a reasonable comparative evaluation be made and that a summary of evaluations with respect to the qualifying condition for each guideline be provided to "allow comparisons to be made among sites on the basis of each guideline."

The evaluation in Chapter 7 is intended to allow the reader to compare the more detailed suitability evaluations of the individual sites that are presented in Chapter 6 of each environmental assessment. The comparison should assist the reader in understanding the basis for the nomination of five sites as suitable for characterization; it is not intended to directly support the subsequent recommendation of three sites for characterization as candidate sites.

\subsubsection{APPROACH AND ORGANIZATION}

This comparative evaluation of the five nominated sites is based on the postclosure and preclosure guidelines (10 CFR Part 960, Subparts B and C, respectively). The approach used to compare the sites with respect to each system and technical guideline is summarized below. 


\subsubsection{Technical guidelines}

Major considerations that could be used to compare the sites on the basis of the qualifying condition of each technical guideline were derived by identifying the favorable, potentially adverse, and disqualifying conditions that deal with the same general topic. Contributing factors that represent the characteristics of the site that are potentially important in evaluating the sites with respect to each major consideration were also identified. The relative importance of the major considerations was determined primarily by the degree to which they contribute to the qualifying condition; that is; the stronger the tie between the consideration and the qualifying condition, the greater the importance of the consideration.

The purpose of identifying major considerations for each guidelines is to combine closely related site conditions so that the balance of the favorable and potentially adverse conditions can be considered directly. Most guidelines that contain a disqualifying condition also have one or more potentially adverse conditions that relate to the disqualifying condition. Since these potentially adverse conditions are considered in the formulation of a major consideration, the important aspects of the disqualifying conditions indirectly enter the comparative evaluation: Where a major consideration that is needed to evaluate the qualifying condition does not have a related favorable or potentially adverse condition; the consideration is derived directly from the qualifying or disqualifying condition.

\subsubsection{System guidelines}

The comparison of sites on the basis of the individual technical guidelines uses the major considerations to incorporate the favorable and potentially adverse conditions in an evaluation of a site's standing on the qualifying conditions for each technical guideline. It is not appropriate, however, to use this approach for a comparative evaluation of sites on the basis of the system guidelines. The qualifying conditions for the system guidelines do not lend themselves to the identification of major considerations in the way that the qualifying conditions for the technical guidelines do. The system guidelines for postclosure repository performance and preclosure radiological safety are stated in terms of regulatory requirements of the NRC and the EPA. The evaluations of these two system guidelines are based on preliminary performance assessments. These evaluations are summarized directly in Chapter 7 from Sections 6.3.2 and 6.2.2.1 of each environmental assessment.

The system guidelines for environmental quality, socioeconomics, and transportation, and for the ease and cost of repository construction, operation, and closure are not stated as regulatory standards, and they cannot be evaluated by a performance assessment as are the other two system guidelines. Instead, they are evaluated by considering the individual guidelines that make up these two system guidelines collectively to determine whether each site meets the qualifying condition of the relevant system guidelines. The evaluation of these system guidelines is sumarized in Chapter 7 from information contained or referenced in Sections 6.2 .2 .2 and 6.3.4 in each environmental assessment. 
This overview summarizes the major considerations and contributing factors for each technical guideline. It does not discuss the comparative evaluations of sites in Chapter 7; these comparisons are already a summary of information in Chapter 6 of each environmental assessment, and the DOE believes that a further synopsis of the evaluation in Chapter 7 for the purpose of this overview would distort the information and possibly mislead the reader. For the systems guidelines, this overview summarizes (1) the conclusions of the performance-assessments for postclosure repository performance and preclosure radiological safety, and (2) the conclusion on the qualifying condition for environmental quality, socioeconomics, and transportation, and the ease and cost of constructing, operating, and closing the repository. For a discussion of the initial order of preference of sites, the reader is referred to the separate report on the multiattribute utility analysis of the nominated sites.

\subsection{COMPARISON OF THE SITES ON THE BASIS OF THE POSTCLOSURE GUIDELINES}

The postclosure guidelines are concerned with the characteristics, processes, and events that may affect the performance of the repository after closure. Their objective is to ensure that the health and safety of the public will be protected for thousands of years, until the radioactivity of the waste has diminished to safe levels.

\subsubsection{TECHNICAL GUIDELINES}

\subsubsection{Geohydrology}

Four major considerations are identified that influence the favorability of the sites with respect to the qualifying condition for the geohydrology guideline. The first consideration, ground-water travel time and flux, addresses geohydrologic conditions that control ground-water travel time between the disturbed zone and the accessible environment, and ground-water flux (volumetric flow rate), across or through the repository and through the host rock to the accessible environment. This is the most important major consideration because transport by ground water is the primary control of radionuclide movement from the repository to the accessible environment. At each of the sites there are uncertainties in the conceptual ground-water flow model and in the values of key hydraulic parameters that control ground-water travel time and flux. Taking these uncertainties into account, there are ranges of possible travel times between the disturbed zone and accessible environment at each site. Therefore, ground-water travel time was stochastically modeled at each site, using reasonably conservative assumptions about the geohydrologic system and ranges of hydraulic parameters. In general, ground-water flux is expected to be low to very low at each of the nominated sites.

The second consideration, changes in geohydrologic processes and conditions, addresses potential changes in natural processes in the geologic setting that could change geohydrologic conditions so as to affect the ability of a repository to isolate the waste. The DOE has concluded that climatic change is the only factor that has a likely potential for significantly 
affecting the hydrologic system at any of the nominated sites during the next 100,000 years. Therefore, climatic change is the only potential cause of change to the geohydrologic system that is addressed in the evaluations of individual sites.

The third consideration is ease of characterizing and modeling the geohydrologic system. Since it is not an intrinsic physical characteristic of the geohydrologic.setting, this consideration is not as important as the first two considerations. Some of the contributing factors that influence the ease of characterization and modeling are the presence of faults, folds, and brine pockets, dissolution effects, lithologic variations, interrelationships among hydrostratigraphic units, availability of testing techniques and analytic models, and understanding of flow mechanisms.

The last consideration, presence of suitable ground-water sources; addresses the possibility that radionuclides migrating from a repository could mix with ground-water sources suitable for crop irrigation or human consumption without treatment along flow paths to the accessible environment. This consideration is less important than the other three, because it is unlikely that ground-water resources could be contaminated if a site is selected on the basis of its ability to isolate wastes, as reflected in the other three considerations.

\subsubsection{Geochemistry}

Three major considerations are identified that influence the favorability of the sites with respect to the qualifying condition for the geochemistry guideline. The first consideration, mass transfer of radionuclides, includes geochemical conditions within the immediate vicinity of the waste package after permanent closure of the repository. The mass transfer of radionuclides is the most important consideration because it describes the processes by which radionuclides that are initially sealed in the waste package as part of the solid waste form will be released to the ground-water system or be contained within the engineered-barrier system. The most important contributing factors include the volumetric flow rate of ground water near (within a few meters) the waste package and the chemistry of the ground water.

The second consideration, radionuclide transport, addresses geochemical conditions outside the immediate vicinity of the waste package after the permanent closure of the repository. Radionuclide transport near the waste package is considered to be slightly less important than the first major condition because geochemical conditions that influence transport may act as a secondary barrier to radionuclides escaping from the engineered barrier system. The contributing factors that are the most important for the quantitative evaluation of this consideration include the potential for sorption and precipitation, and redox conditions.

The last consideration addresses geochemical processes that could adversely affect the sorptive capacity or strength of the host rock, or both. This is the least important consideration under the geochemistry guideline because mineral alteration and changes in rock strength in the vicinity of the waste-package would affect only a small percentage of the total rock mass surrounding the repository. The major contributing factors for this 
consideration are the stability of mineral assemblage and effects of changes in the structure of minerals on sorption and rock strength.

\subsubsection{Rock characteristics (postclosure)}

Three major considerations are identified that influence the favorability of the sites with respect to the qualifying condition for rock characteristics guideline. The first consideration is the impact on waste isolation of repository-induced heat. "The contributing factors for this condition are thermal properties of the host rock such as its ability to conduct heat or expand in response to heat; mechanical properties such as ductility; thermomechanical behavior such as the potential for thermally induced fractures; and geochemical factors such as the potential for brine migration, hydration, or dehydration of the mineral components. The impact of repository-induced heat is the most important of the three major considerations because' it has the greatest potential for affecting waste isolation.

The complexity of engineering measures is the second major consideration. It addresses in situ characteristics and conditions that could require engineering measures beyond reasonably available technology to ensure waste containment and isolation. The major contributing factors to this consideration are the uncertainty in the integrity of man-made sealing materials during the postclosure period and the effects of the in situ environment on the performance of engineered-barriers (such as the effects of brine on the waste-disposal container). Complexity of engineering methods is considered less important than repository-induced heat effects because of the greater potential of repository-induced heat to impair the isolation capabilities of the site.

The last consideration for this guideline is whether the host rock is large enough to allow flexibility in determining the depth, configuration, and location of the underground facility. Added flexibility in locating the repository will help avoid geologic features or anomalies that could adversely affect the isolation capabilities of the site. Even after requirements for preclosure host-rock flexibility have been satisfied, added flexibility is still necessary to satisfy this postclosure consideration in terms of depth of excavations, orientations of drifts and where they intersect, and location of seals. A greater volume of host rock could provide isolation capability over and above the degree deemed minimally acceptable. However, the contribution to waste isolation added flexibility in locating the underground facility is less than that of the other two considerations for this guideline.

\subsubsection{4 climatic changes}

One major consideration, the effects of climatic changes in the future on the ability of the site to isolate waste, is identified that influences the favorability of the sites with respect to the qualifying condition for the climatic changes guideline. The major contributing factors to this : , ............. 
consideration are climatic cycles during the Quaternary Period and in situ conditions at a site.

\subsubsection{Erosion}

The single major consideration under this guideline is the potential effects of erosion on the ability of the repository to isolate wastes. Contributing factors include the depth of waste emplacement, evidence of extreme erosion during the Quaternary Period, the potential for the waste to be exhumed by erosion, and the assessment of future erosion rates and geomorphic processes.

\subsubsection{Dissolution}

The single major consideration for this guideline is evidence of dissolution of the host rock during the Quaternary Period. The contributing factors for this consideration include the solubility of the host rock under nonextreme geologic and hydrologic conditions, and unusual ground-water chemistry.

\subsubsection{Tectonics (postclosure)}

The single major consideration for this guideline is the potential for increased igneous and tectonic activity during next 10,000 years and the effect that these processes have on radionuclide releases. The contributing factors include evidence of tectonic or igneous activity during the Quaternary Period, the likelihood of tectonic and igneous events during the next 10,000 years that could alter the regional ground-water flow system, the historical record of seismicity, the correlation of earthquakes with tectonic features, and evidence of tectonic activity during the Quaternary Period.

\subsubsection{Human Interference}

The potential for human interference after the repository is closed and decommissioned requires an analysis of (1) the natural resources at or near a site, including past, current, and future exploration for and uses of these resources and $(2)$ site ownership and control.

\subsection{Natural resources}

Three major considerations are identified that influence the favorability of the sites with respect to the qualifying condition for the natural resources guideline. Although the major considerations are listed in decreasing order of importance, there are relatively small differences in importance, particularly between the second and third considerations. 
The first consideration is evidence of subsurface mining, resource extraction, and drilling at the site. It assesses the impacts on the isolation and containment system from existing mines and drill holes within the site.

The second consideration is the potential for foreseeable human activities that could affect the ability of the site to contain and isolate wastes. Contributing factors include the potential for ground-water withdrawal, irrigation, injection of fluids, underground pumped storage, and large-scale surface-water impoundments. This consideration is not as important as the first major consideration because the first consideration is based on existing evidence of resources, while the second is based on projected, more speculative human activities. In evaluating this major consideration the environmental assessments have qualitatively considered the effectiveness of markers and records in reducing the potential for of human intrusion in the controlled area.

The last major consideration, potential for intrusion to extract resources after the repository is closed. Contributing factors include the presence or indications of resources (including water) at the site, their value, scarcity, and depth, and whether they are available from other sources. This consideration is third in importance because the potential for resources is based on speculative or indirect evidence.

\subsection{Site ownership and control}

The purpose of the postclosure guideline on site ownership and control is to help ensure that the repository can function far into the future without adverse human interference. This guideline specifies that the DOE, in accordance with the requirements of $10 \mathrm{CFR}$ Part 60 , must obtain ownership of surface and subsurface rights to land and minerals within the controlled area of the repository. A similar guideline on site ownership is also provided for the preclosure period. The DOE has determined that the necessary land area and controls are the same for both the postclosure and preclosure periods at the five nominated sites. Whichever site is selected, the DOE must obtain ownership and surface and subsurface rights before beginning construction; there is no basis for distinguishing among the sites on the basis of their site ownership and control status at the beginning of the postclosure period.

\subsubsection{POSTCLOSURE SYSTEM GUIDELINE}

The results of preliminary system-performance assessments are described in Section 6.4 .2 of each environmental assessment and briefly reviewed here. These preliminary assessments are based on 1imited geologic, hydrologic, and geochemical information, preliminary conceptual models, and relatively simple analytical techniques. The DOE is therefore not yet prepared to provide assurance that the regulatory criteria will be met at any of the sites. These preliminary assessments do, however, appear adequate to evaluate the sites in terms of the postclosure system guideline. 
The guideline addresses the following capabilities of the geologic setting at a site:

1. The capability of the geologic setting at the site to allow for the physical separation of the waste from the accessible environment after closure in accordance with the requirements of the EPA standard in 40 CFR Part. 191, Subpart B, as implemented by the NRC rule in 10 CFR Part 60.

2. The capability of the geologic setting at the site to allow for the use of engineered barriers to ensure compliance with the requirements of the EPA and the NRC. Two requirements are pertinent here: (1) the time of substantially complete containment (i.e., a period between 300 and 1,000 years); and (2) the 1 imit on the rate of radionuclide releases from the engineered-barrier system (i.e., one part in 100,000 per year of the individual radionuclide inventory or one part in 100,000 per year of the total inventory calculated to be present at 1,000 years af ter repository closure, whichever is greater).

With regard to the capability of the geologic setting to separate the waste from the accessible environment, the results of the preliminary assessments do not exceed the EPA standard at any of the sites. For example, the mean ground-water travel time from the repository to the accessible environment is expected to be much longer than 10,000 years at all five nominated sites.

Because of the different characteristics of the sites, different approaches to the performance assessments and different levels of conservatism have been used for each site. : Since site-specific data is limited prior to characterization, the degree of conservatism resulting from such assumptions in each case is not currently known. Nonetheless; the degree of conservatism is believed to be sufficient to establish outside bounds on actual site performance. The preliminary performance assessments do not provide any reason to believe that any of the sites would not adequately isolate the waste from the accessible environment.

With regard to the requirements for the performance of the engineeredbarrier system, the preliminary assessments indicate that the system would meet the regulatory performance objectives at all sites. For example, analyses of the waste-package performance indicate that the container lifetime is expected to exceed the 300- to 1,000-year requirement for substantially complete containment at each site. For each site, the calculations of the rate of radionuclide release after the failure of the waste package suggest that the criterion for the rate of release from the engineered-barrier system would not be exceeded. Extremely conservative assumptions have been used to make these estimates. Again, the degree of conservatism provided by these assumptions is not presently known: However, the DOE is confident that the use of conservative assumptions establishes outside bourids on actual performance of the waste package, and the analyses appear to be sufficient to indicate that there is no evidence that the criteria for the performance of the waste-package and engineered-barrier systems would not be met at each of the nominated sites. Furthermore, the available data and the preliminary analyses based on these data have not identified any conditions or features at any of the sites that would prevent these engineered components from meeting the performance requirements.

$$
-27-
$$




\subsection{COMPARISON OF SITES ON THE BASIS OF PRECLOSURE GUIDELINES}

The preclosure guidelines address (1) preclosure radiological safety; (2) the environmental, socioeconomic, and transportation-related impacts associated with repository siting, construction, operation, and closure; and (3) the ease and cost of repository siting, construction, operation, and closure. Both technical and system guidelines are provided for each of these three categories.

\subsubsection{PRECLOSURE RADIOLOGICAL SAFETY}

\subsubsection{Technical guidelines}

There are four technical guidelines that contribute to the assessment of preclosure radiological safety: (1) population density and distribution, (2) site ownership and control, (3) meteorology, and (4) offsite installations and operations. The objective of these guidelines is to protect the health and safety of the public and the workers at the repository by keeping exposures to radiation within the limits prescribed by regulations.

\subsection{Population density and distribution}

Two major considerations are identified that influence the favorability of the sites with respect to the qualifying condition for the population density and distribution guideline. The first major consideration is the remoteness of a site as measured by the site's distance from highly populated areas of 2,500 people or more, or from a one mile by one mile (2.6 square kilometers) area that contains 1,000 or more individuals. The contributing factors for this consideration are the air distance of the site from population concentrations and the size of those concentrations.

The second major consideration, population density, is evaluated for each site on the basis of density within the projected site boundaries, near the site (within a radius of $10 \mathrm{miles}$ ), and in the general region of the site (within a radius of 50 miles). In the evaluation of this major consideration, a "low population density" is defined as being less than the average population density of the contiguous United States in 1980, or 76 persons per square mile.

\subsection{Site ownership and control}

The single major consideration for this guideline is the complexity of procedures for acquiring land needed for the repository. The DOE has evaluated this guideline on the basis of what property would be required for repository construction, operation, closure, and decommissioning.: Land acquisition procedures, such as leasing, that might be employed during site characterization are not considered in the evaluation of this guideline. 
Sites for which land will be easier to acquire from a procedural and legal point of view are more favorable than sites that are more difficult to acquire. This does not mean that the DOE discounts the socioeconomic impact of acquiring land, especially privately-owned land. The socioeconomic impacts of land acquisition are considered under the socioeconomic guideline.

\subsection{Meteorology}

Two major considerations are identified that influence the favorability of the sites with respect to the qualifying condition for the meteorology guideline. The first major consideration is conditions that affect the transport of radionuclides in the atmosphere to unrestricted areas where the public might be exposed, and the significance of transport. Contributing factors include dispersion characteristics of the atmosphere, wind speed and direction, frequency of stagnation episodes, atmospheric mixing levels, local terrain, and locations of nearby population concentrations. This is the most important consideration under this guideline because the potential for radionuclides to be transported in the direction of population concentrations directly affects a site's ongoing ability to meet the requirements of the preclosure system guideline for radiological safety, and reflects the focus on routine exposures in the qualifying condition for meteorology.

The second major consideration, extreme-weather phenomena, addresses the historical frequency and intensity of extreme weather such as hurricanes, tornadoes, floods, and winter storms that could have a significant effect on repository operations or closure. This consideration is less important than the first major consideration because, unlike atmospheric transport characteristics, which tend to reflect on-going or frequent meteorological conditions, extreme weather phenomena reflect infrequent or episodic conditions.

\subsection{Offsite installations and operations}

Two major considerations are identified that influence the favorability of the site with respect to the qualifying condition for the of installations and operations guideline. The first major consideration is the presence of nearby nuclear installations or operations. This consideration addresses radionuclide releases from atomic energy defense activities and nuclear installations regulated by the NRC, which could, together with operational releases from the repository, subject the general public to radionuclide exposures above allowable limits. The evaluation of this consideration accounts for the proximity of nuclear installations and operations to the site and the level of radionuclide releases during accidents and routine operating conditions at these installations.

The second major consideration is the possible adverse effects of nearby hazardous operations and installations on repository, construction, operation, and closure. Such operations and installations could include chemical plants; fuel production, refining, transportation, and storage facilities; pipelines; major transportation routes that could carry hazardous materials; air traffic 
associated with nearby airports; military operations areas; and facilities that handle toxic materials including hazardous waste disposal sites.

\subsubsection{Preclosure system guideline for radiological safety}

For preclosure radiological safety the pertinent system elements are (1) the site-specific characteristics that affect radionuclide transport; (2) the engineered components whose function is to control releases of radioactive materials; and (3) the people who, because of their location and distribution in unrestricted areas, may be affected by radionuclide releases. This guideline is assigned the greatest importance among the three preclosure system guidelines because it is directed at protecting both the public and the repository workers from radiological exposures.

This guideline requires that projected radiological exposures of the general public and projected releases to restricted and unrestricted areas during the preclosure period shall meet applicable requirements set forth in 10 CFR Part 20, 10 CFR Part 60, and 40 CFR 191, Subpart A. The specific requirements of these regulations and how well each site performs against these regulations are detailed in performance assessments that are presented in Section 6.4.1 of each environmental assessment. On the basis of these preliminary assessments it appears that a repository can be located and operated at any of the nominated sites with insignificant radiological exposure risks to the pub1ic.

\subsubsection{ENVIRONMENT, SOCIOECONOMICS, AND TRANSPORTATION}

\subsubsection{Technical guidelines}

Three technical guidelines are associated with the preclosure system guideline for environmental quality, socioeconomics, and transportation. Their objective is to ensure that the well being of the public and the quality of the environment are adequately protected from the hazards posed by the disposal of radioactive wastes.

\subsection{Environmental quality}

Four major considerations are identified that influence the favorability of the sites with respect to the qualifying condition for the environmental quality guideline. The first major consideration is the ability of a site to meet applicable environmental requirements. This consideration addresses the procedural and substantive requirements of environmental regulations with which the repository project must comply. A site's standing against this consideration is determined by evaluating the degree to which project activities will comply with applicable requirements as well as their ability to do so within specific time constraints. 
The second major consideration is the significance of environmental impacts that could arise from the project and the degree to which such impacts can be mitigated. It also considers features of the mitigation measures such as their time requirements and technological feasibility, and the social, economic, or environmental factors that affect their applicability to a particular site. Because the environmental requirements and environmental impact considerations both reflect the requirement in the qualifying condition that the quality of the environment as a whole must be protected, these considerations are of equal importance. At the same time, they are each more important than either of the two remaining considerations.

The third major consideration is effects of the repository on protected Federal resource areas. It addresses the following Federal lands: the National Park System, the National Wild1ife Refuge System, the National Wild and Scenic Rivers System, the National Wilderness Preservation System, and National Forest Land, as well as designated critical habitats for threatened or endangered species. The evaluation of sites for this consideration is based on their proximity to, and the degree of projected impacts on, the listed areas, except for critical habitats. Critical habitats are considered on the basis of whether they could be compromised by the repository.

The fourth major consideration under the environmental quality guideline is impacts on protected State or regional resource areas, Native American resources, and cultural sites. The evaluation of this consideration addresses the combined effects of a site's proximity to resource areas and the projected level of impact on those areas. Because these last two considerations address the protection of the environment in terms of a subset of environmental conditions (i.e., speciflc resource areas), they are equally important as a group, but less important than the first two considerations.

\subsection{Socioeconomic impacts}

Six major considerations are identified that influence the favorability of the sites with respect to the qualifying condition for the socioeconomics guideline.

The first consideration is potential impacts to commity services and housing. This consideration relates to the requirement in the qualifying condition that impacts on community services or housing in affected areas and communities can be mitigated or compensated. Impacts on community services and housing depend on five contributing factors: population composition and density, the distribution of in-migrants, current capacity and trends in use of community services and infrastructure, housing supply and demand, and the ability of affected comminities to accommodate growth.

The second major consideration is potential impacts on direct and indirect employment and business sales. Two factors contribute to the evaluation of this consideration: project-related needs for labor and expected local hires, and local project-related purchases of materials. 
The third major consideration is potential impacts on primary sectors of the economy. The three contributing factors for this consideration are the major sectors of the economy, employment distribution and trends by economic sector, and the compatibility of a repository with the economic base of the affected area.

The fourth major consideration is potential impacts on the revenues and expenditures of public agencies in the affected area. Impacts on revenues and expenditures depend on three contributing factors: the sources of, and trends in, expenditures and revenues of local government, the additional needs for community services induced by the repository project, and economic growth in the area and resulting increases in tax revenues associated with the repository.

The fifth major consideration is the need to purchase or acquire water rights that could affect development in the area. The need to acquire water rights depends on two contributing factors: project-related water requirements, and current water rights, use, and capacity.

The last major consideration under the socioeconomics guideline is potential social impacts. Three factors contribute to the potential for social impacts: the quality of life and existing social problems in the affected communities, the size of the in-migrating population in comparison to the existing population, and the compatibility of the in-migrating population with the lifestyles and characteristics of the current residents.

\subsection{Transportation}

Four major considerations are identified that influence the favorability of sites with respect to the qualifying condition for the transportation guideline. The first and most important major consideration is transportation safety. Contributing factors include the distance of travel, the location of access routes, local terrain, and regional weather conditions.

The second major consideration is the environmental impacts of improving the existing infrastructure and of constructing new access routes to the site. For example, transportation operations and development of access routes might adversely affect sensitive species on a large scale (over many miles), and the aesthetic quality of the region may be degraded by the construction of road and rail routes. This consideration focuses on local conditions around the site since the environmental concerns along the national highway and rail network were already considered during the development of those networks for regular commercial traffic. In this respect, the incremental environmental impacts of transporting radioactive wastes are not considered to be significant on a national scale. Contributing factors for this consideration include the need to construct lengthy access roads, conflicts with current land use plans, and the need for cuts, fills, tunnels, or bridges to reach the site. 
The third major consideration is the cost of constructing and upgrading the access routes to the sites. This is not as important as the first consideration since the protection of health and safety is more important than reducing costs. The main contributing factors that influence costs are the extent of needed repairs, local terrain, and costs for rights-of-way.

The least important consideration is the cost of developing the cask fleet and shipping the wastes to the repository. The cost of transporting spent fuel to the repository is determined, in part, by the distance of the site from the spent-fuel sources. Nonetheless, it costs about as much to ship waste 1,000 miles as it does 500 miles. This consideration, as well as the consideration of transportation safety, is also affected by decisions about the configuration of the waste-management system, such as the second repository. The effect of the second repository is considered as quantitatively as possible. Other contributing factors include local weather conditions, availability of carriers, emergency-response capabilities, legal impediments to transport, and the number of railway crew changes.

\subsubsection{System guideline on environment, socioeconomics, and transportation}

Ranked second in importance in the preclosure system guidelines is environment, socioeconomics, and transportation. The pertinent system elements will, in general, consist of (1) the people who may be affected, including their lifestyles, sources of income, social and aesthetic values, and community services; (2) the air, land, water, plants, animals, and cultural resources in the areas potentially affected by such activities; (3) the transportation infrastructure; and (4) the potential mitigating measures that can be used to achieve compliance with this guideline.

On the basis of the evaluation of the guidelines for environmental quality, socioeconomics, and transportation, the evidence does not support a conclusion that the qualifying condition for this system guideline would not be met at any of the nominated sites.

\subsubsection{EASE AND COST OF SITING, CONSTRUCTION, ORERATION, AND CLOSURE}

\subsubsection{Technical guidelines}

The four technical guidelines in this group address the surface characteristics of the site, the characteristics of the host rock and the surrounding strata, hydrologic conditions, and tectonics. These guidelines are concerned with the ease and cost of siting, constructing, operating, and closing the repository. 


\subsection{Surface characteristics}

Two major considerations are identified that influence the favorability of the sites with respect to the qualifying condition for the surface-characteristics guideline. The first consideration is the potential for flooding of surface or underground facilities. This is the most important consideration under this guideline because the effects of flooding can be important factors in the design of the repository. The primary contributing factors for this consideration include the location and likelihood of flooding due to natural causes at the surface or in the underground facilities, or the potential for failure of man-made surface water impoundments or engineered components of the repository.

The second consideration is the effects of the terrain and drainage characteristics of a site on repository construction, operation, and closure. It is less important than the first consideration because terrain and drainage are more closely related to the ease and cost of construction than to safety, and can generally be mitigated more readily than conditions that could cause flooding (i.e., the first consideration). Contributing factors for this major consideration include the configuration of the repository, the potential for landslides, and soil characteristics.

\subsection{Rock characteristics (preclosure)}

Three major considerations are identified that influence the favorability of the sites with respect to the qualifying condition for the rock characteristics guideline. The first consideration addresses in situ conditions that could lead to safety hazards or difficulties during repository siting, construction, operation, and closure, including retrieval. Because of the DOE's emphasis on safety of personnel, this is the most important major consideration of the three related to this guideline.

The second consideration addresses in situ characteristics and conditions that could require engineering measures beyond reasonably available technology in the construction of shafts and underground facilities. Al though the success of repository construction depends on its technical feasibility, the complexity of engineering measures is second in importance to personnel safety because of the DOE's primary emphasis on safety.

The third major consideration is whether the host rock is large enough to allow flexibility in selecting the depth, configuration, and location of the underground facility. This consideration is judged to be third in importance, because although adequate host rock to accommodate a repository is necessary, and additional host rock to provide flexibility is desirable, it is not as essential as worker safety and technical feasibility. 


\subsubsection{3, Eydrology}

Three major considerations are identified that influence the favorability of the sites with respect to the qualifying condition for the preclosure hydrology guideline. The first major consideration is ground-water conditions that could necessitate complex ground-water control measures in shafts and drifts during repository siting, construction, operation, and closure. This is the most important consideration because it has the most impact on the ease and cost of repository construction, operation, and closure.

The second major consideration is the existence of surface-water systems that could flood the repository. This consideration includes ponds, lakes, streams, and man-made impoundments that could flood the underground workings. Surface-water flooding of the underground workings is a concern because it could endanger the safety of personnel and interrupt repository operations. However, standard engineering measures such as dikes and berms can minimize the risk of flooding. This consideration is considered second in importance because it is generally easier to manage the potential for surface flooding than underground flooding.

The last major consideration under this guideline is the availability of an ample source of ground or surface water for repository construction, operation, and closure. "This consideration is third in importance because, although it affects the ease and cost of construction, it has a limited effect on the technical feasibility of developing the repository.

\subsection{Tectonics (preclosure)}

Two major considerations are identified that influence the favorability of the sites with respect to the preclosure tectonics guideline. The first consideration is the potential for earthquake ground motion at the site. This consideration requires an evaluation of whether ground motion at the site could lead to safety hazards or difficulties during repository siting, construction, operation, and closure. The evaluation of ground motion depends on the evaluation of potential surface faulting in the geologic setting. Contributing factors for this major consideration include the historical earthquake record, evidence of man-induced seismicity, estimates of ground motion from historical and man-induced earthquakes, correlation of earthquakes with tectonic structures and faults, and evaluations of the effects of ground-motion hazards on design.

The second consideration, expected impact of fault displacement at the site, requires an assessment of the potential for fault displacement at the site that could lead to safety hazards or difficulties during repository siting, construction, operation, and closure. This consideration is about equal in importance to the potential for earthquake ground motion. Although the likelihood of faulting at a site is generally lower than the likelihood of ground motion, the need to design for fault displacement can have a significant effect on the site's favorability. Successful construction experience where fault displacement conditions exist is an important contributing factor to this consideration. The other major contributing factors are the evidence and location of, and rates of movement on, Quaternary faults in the geologic setting. 


\subsubsection{System guideline on the ease and cost of siting, construction operation, and closure}

The third preclosure system guideline is ease and cost of siting, construction, operation, and closure. It is ranked lowest because it does not directly relate to the health, safety, and welfare of the public or the quality to the environment. Here the pertinent elements are (1) the site characteristics that affect siting, construction, operation, and closure; the engineering, materials, and services necessary to conduct these activities; (3) written agreements between the DOE and affected States and affected Indian tribes and the Federal regulations that establish the requirement for these activities; and (4) the repository personnel at the site during siting, construction, operation, or closure.

On the basis of the technical guidelines for ease and cost of repository siting, construction, operation, and closure, the evidence does not support a conclusion that the qualifying condition for this system guideline would not be met at any of the nomimated sites. 